\title{
How interactions influence customer empowerment and satisfaction in the retail industry
}

\author{
Javier Castillo \\ USPG Business School \\ Universidad San Pablo de Guatemala, Guatemala
}

\section{Keywords}

Customer empowerment, customer satisfaction, retail, interaction, consultative selling process

\begin{abstract}
Interactions with consumers in a retail environment play a fundamental role to increase sales, improve satisfaction and promote loyalty among such consumers, at the same time of improve financial results that may sustain a company long-term. Such face-to-face or online interactions have several components that may cause an improved State of Empowerment perception resulting in a relevant satisfaction, thus, loyalty and retention. For such purpose, the actual study comes to analyze what are those behaviors or actions that bring into play such perception, and how such perception relates to an improved customers' satisfaction.

This document aims to prove the importance of such behaviors when interacting with consumers in online or face-to-face retail transactions, and how such behaviors need to be reflected and exploited when connecting with customers.
\end{abstract}

Corresponding author: Javier Castillo

Email addresses for corresponding author: jcastillo@uspg.edu.gt

First submission received: $3^{\text {rd }}$ January 2018

Revised submission received: 22 $2^{\text {nd }}$ February 2018

Accepted: $3^{\text {rd }}$ May 2018

Introduction

How businesses should interact with customers to achieve Customer Satisfaction and Empowerment is a fundamental area of study among all companies with special emphasis in the retail industry. This has a deeper relevance when brick-and-mortar stores are experiencing a traffic reduction while on-line retailing is growing considerably. Understanding how Empowerment can be achieved when there is a positive interaction with consumers may contribute to sell more and have more loyal customers. Therefore, this research aims to help companies understand what actions should be relevant to achieve such sense of empowerment among consumers, and consequently, an improved satisfaction experience and loyalty, which may result in better financial outcomes (Di Mascio, 2010; Grewal, Krishnan \& LindseyMullikin, 2008; Hunter \& Garnefeld, 2008; Liu \& Leach, 2001).

\section{Literature Review and Hypotheses}

Customer satisfaction plays a significant role to achieve growth and loyalty. Therefore, companies aim to improve such satisfaction through efficient interactions using service and value as their main focus. Most companies constantly look for ways to improve satisfaction when relating with consumers, however, a sentiment of empowerment and control has proven to be as important as interactions when promoting such satisfaction. Thus, employees play a significant role bringing value to any interaction with consumers while showing the right attitude and supporting the most significant actions to promote such perception of satisfaction and attain success in the short and long term (Di Mascio, 2010; Hennig-Thurau, 2004; Hunter \& Garnefeld, 2008; Muyeed, 2012; Sainy, 2010; Thenmozhi \& Dhanapal, 2010; Wicks \& Roethlein, 2009).

\section{Consultative Selling Process}

As stated by Castillo (2017) the consultative selling process (CSP) is the process where consumers interact with employees and decide how to act in a business transaction (Liu \& Leach, 2001). Then, employees representing the company need to cooperate and share information with consumers that may 
contribute to satisfy their needs in an effective way. Also, they need to advise consumers on how to find a good solution to actual needs and never be just ordinary promoters (Liu \& Leach, 2001; Suomala, et al., 2012).

Therefore, throughout this process, employees should consider customers' needs while suggesting a solution and solving their objections (Graziano \& Flanagan, 2005; Suomala, et al., 2012). Thus, CSP aims to surpass customers' expectations and attain sales while serving consumers (Suomala, et al., 2012).

\section{Customer Satisfaction}

Customer Satisfaction as stated in Castillo (2017) is defined as "past and present events, where a positive experience compared to actual expectations and previous interactions results in a high satisfaction which also improves consumers' loyalty and has a positive relationship with customer service" (p.12). Thus, satisfaction among consumers increases retention and loyalty, aiming to significant positive financial results in the short and long-term (Hennig-Thurau, 2004; Wicks \& Roethlein, 2009). Then, consumers' satisfaction is key to success, good financial results and increased market share (Ivanauskienė, Auruškevičienė, Škudienė \& Nedzinskas, 2012).

\section{Customer Empowerment and Its Relationship with Satisfaction}

Customer Empowerment may be defined as a state of empowerment perception, and such perception results from an interaction where consumers have access to better information, driving them to understand all related aspects involved in a sale transaction or product (Fuchs, Prandelli \& Schreier, 2010; Hunter \& Garnefeld, 2008; Pranic \& Roehl, 2012). Thus, throughout this interaction an increase of control is perceived, which not necessarily means real control, promoting a positive ownership sentiment (Hunter \& Garnefeld, 2008; Pranic \& Roehl, 2012). As a result of this, customer empowerment can be perceived in any transaction or exchange of services which results in a better satisfaction perception or experience, an increase in loyalty, retention, and better financial results (Castillo, 2017; Hunter \& Garnefeld, 2008; Pranic \& Roehl, 2012).

\section{Online Interaction}

Focus on different aspects compared to a face-to-face interaction. Such online interaction gives consumers a sense of self-selection, however, it lacks a comprehensive interaction where frontline employees share information and resolve customers' needs. Also, such interaction and electronic commerce allow companies to expand in a more effective way, yet, it also bring problems such as customers failing to understand the whole purchase experience, or sellers unable to understand habits, expectations and motivations of consumers (Ortiz-Betancourt, Meza-Téllez \& Terrones-Castro, 2017). Also, for successful online sales, sellers need to understand what products need to be available, what promotions need to be developed, and how services need to be advertised among consumers (Shrivastava \& Shrivastava, 2017).

\section{Retail Industry}

As defined by Kotni (2011), retailing represents all activities performed when offering services or products among consumers. The retail industry is considered fundamental in many countries around the world, representing the health of their economies, and being deeply dynamic and very reactive to turnarounds. Such industry is composed of people and institutions providing products or services on demand to ultimate users (Deloitte, 2014; IMAP Inc., 2010; International Markets Bureau [IMB], 2011; Kotni, 2011; KPMG, 2013).

\section{Hypotheses}

Based on the concepts described above where perception of satisfaction and empowerment are explained, and using data of Castillo (2017), the following hypotheses were developed:

${ }_{1} \mathrm{H}_{1}$ : There is a significant positive relationship between Customer Empowerment evoked during the consultative selling process and Customer Satisfaction, having as null hypothesis ${ }_{1} \mathrm{H}_{0}$ : There is no significant positive relation between Customer Empowerment evoked during the consultative selling process and Customer Satisfaction. 
${ }_{2} \mathrm{H}_{1}$ : There is a significant positive relationship between all Understanding Needs and Customer Satisfaction, having as null hypothesis ${ }_{2} \mathrm{H}_{0}$ : There is no significant positive relation between Understanding Needs and Customer Satisfaction.

${ }_{3} \mathrm{H}_{1}$ : There is a significant positive relationship between Understanding Needs and Customer Empowerment, having as null hypothesis ${ }_{3} \mathrm{H}_{0}$ : There is no significant positive relation between Understanding Needs and Customer Empowerment.

${ }_{4} \mathrm{H}_{1}$ : There is a significant positive relationship Customer's Preferences and Customer Satisfaction, having as null hypothesis ${ }_{4} \mathrm{H}_{0}$ : There is no significant positive relation between Customer's Preferences and Customer Satisfaction.

${ }_{5} \mathrm{H}_{1}$ : There is a significant positive relationship between Customer's Preferences and Customer Empowerment, having as null hypothesis ${ }_{5} \mathrm{H}_{0}$ : There is no significant positive relation between Customer's Preferences and Customer Empowerment.

${ }_{6} \mathrm{H}_{1}$ : There is a significant positive relationship between Suggesting Products to Customers and Customer Satisfaction, having as null hypothesis ${ }_{6} \mathrm{H}_{0}$ : There is no significant positive relation between Suggesting Products to Customers and Customer Satisfaction.

${ }_{7} \mathrm{H}_{1}$ : There is a significant positive relationship between Suggesting Products to Customers and Customer Empowerment, having as null hypothesis ${ }_{7} \mathrm{H}_{0}$ : There is no significant positive relation between Suggesting Products to Customers and Customer Empowerment.

The author of this document aims to expose the relationship between customers' empowerment and satisfaction with specific interactions, and how these interactions may contribute to improve sales among retail businesses.

\section{Method \\ Purpose of the Study}

The purpose of this study is to determine if there is a relationship between certain interactions in a retail environment with Customer Empowerment and Customer Satisfaction. Then, contribute to establish the importance of such interactions in any transaction to increase loyalty and sales, and provoke a discussion that may serve for future developments and other analysis on this area.

This document aims to reach the following objectives:

- Understand the relationship between Customers' Empowerment and Satisfaction.

- Understand the relationship between Understanding Needs and Customer Satisfaction or Empowerment in a retail transaction.

- Understand the relationship between Customer's Preferences and Customer Satisfaction or Empowerment in a retail transaction.

- Understand the relationship between Suggesting Products and Customer Satisfaction or Empowerment in a retail transaction.

\section{Questionnaire Development, Dependent and Independent Variables}

As described on appendix B, independent variables of Understanding Needs, Customer's Preferences, Suggesting Products and State of Empowerment were used for the present study. Also, dependent variables of Customer Satisfaction and State of Empowerment were utilized to measure the relationship between independent and dependent variables (Creswell, 2013; Castillo, 2017).

More, questions described below were used to assess the dependent variables of customer empowerment and satisfaction as follows:

- Feeling empowered or with enough control during a selling process is important for you as a customer? This question evaluated the relevance of the dependent variable Customer Empowerment.

- Receiving more service from a frontline employee compare to what you were expecting makes you buy more or feel better? This question contributed to evaluate the relationship with the dependent variable Customer Satisfaction.

Last, the following questions were used to analyze independent variables: 
- Do you buy more from a salesperson that understands your needs? This question evaluates relevance of perception that customer's needs has been understood (Liu \& Leach, 2001; Palokangas, 2010; Suomala, Palokangas, Leminen, Westerlund, Heinonen \& Numminen, 2012).

- Do you buy more from a salesperson that asks if you like something that is being suggested by him based on your needs? This question evaluates relevance of independent variable customers' preferences (Abdullah, Abdurahman \& Hamali, 2013; Homburg, Wieseke \& Bornemann, 2009).

- Do you buy more from a salesperson that suggests several products to you based on your needs? This question evaluates relevance of independent variable suggesting products to consumers based on their needs, or suggesting products (Chakrabarty, Brown \& Widing, 2010; Palokangas, 2010; Saxe \& Weitz, 1982; Smith, 2012; Wachner, Plouffe \& Grégoire, 2009). analysis.

This questionnaire and data were part of Castillo (2015), and the present research derives of such

\section{Analysis Method}

This research uses a quantitative analysis to attain the described objective and to make the necessary statistical analysis defined on Appendix B (Creswell, 2013).

\section{Sampling Methods and Procedures}

This study used a random sample, where the stratified population had equal opportunity of being selected (Creswell, 2013). The sample was defined as Facebook's monthly active users with a high-school diploma, more than 21 years old, willing to answer the survey, speaks Spanish or English, and lives in any country that speaks such languages. As of March 31st, 2014 Facebook, had 1.28 billion monthly active users (Facebook, 2014). The data was also used by Castillo (2015).

\section{Sample size.}

Sample size was calculated using the formula proposed by Adams, Khan, and Raeside (2007):

$\mathrm{n}_{0}=\mathrm{Z}_{\propto / 2}^{2} \frac{\mathrm{p}(1-\mathrm{p})}{\mathrm{d}^{2}}$

Where $\mathrm{n} 0=$ sample size, $\mathrm{Z}=$ Standardized normal value, $\mathrm{a}=$ level of significance, $\mathrm{p}=$ estimated rate, $d=$ precision range. as follows:

Then, knowing the population size $(\mathrm{N})$, the finite population correction (FPC) formula was used

$$
\mathrm{n}=\frac{\mathrm{Nn}_{0}}{\mathrm{~N}+\mathrm{n}_{0}}=\frac{\mathrm{n}_{0}}{1+\frac{\mathrm{n}_{0}}{\mathrm{~N}}}
$$

Hence, the parameters defined for this sample size were:

$90 \%$ confidence level due to language limitation and questions interpretation $(\mathrm{Z})$.

$5 \%$ margin error $(\mathrm{d})$.

A response distribution of $50 \%(\mathrm{p})$.

As stated on Castillo (2015), the above formulas conformed a minimal sample size of 271 surveys, and the total response rate was $50.88 \%$ out of 566 surveys distributed between March and May 2014 .

\section{Sample procedures.}

A random sample was used to promote the web-survey using Facebook (Creswell, 2013). The format of the web-survey was a self-administered questionnaire (Appendix A). Facebook ads were published using the criteria described above, and a link to a web-survey using website javiercastillo.org was provided. A raffle of an iPad Mini was promoted among participants with a full response, and a disclosure with the use of such information was posted at the beginning of the survey (Creswell, 2013). Also, participation was based on the standards 3.10 and 8.02 for informed consent as required by the American Psychological Association (2014). Last, to validate authenticity, responder's IP address was saved for future reference and email address was requested to participate in the raffle. 


\section{Results}

Participant Profile

As stated on Castillo (2015), survey's data was collected using the LimeSurvey ${ }^{\circledR}$ open source survey application, and the website javiercastillo.org. A response rate of $19.74 \%$ (based on completed surveys) was achieved from 1,459 users that showed interest on the advertisement promoting the survey. A total of 566 respondents were registered in the system, 278 questionnaires were not considered completed for not being totally finalized, and 288 surveys were recorded as completed.

Furthermore, people of 22 countries answered the survey as follows:

Table 1: Responses by Country

\begin{tabular}{lll}
\hline Country & Responses & $\%$ \\
\hline Argentina & 3 & $1.04 \%$ \\
Bolivia & 43 & $14.93 \%$ \\
Canada & 4 & $1.39 \%$ \\
Chile & 3 & $1.04 \%$ \\
Colombia & 5 & $1.74 \%$ \\
Egypt & 10 & $3.47 \%$ \\
France & 1 & $0.35 \%$ \\
Ghana & 1 & $0.35 \%$ \\
Guatemala & 15 & $5.21 \%$ \\
Honduras & 6 & $2.08 \%$ \\
Indonesia & 4 & $1.39 \%$ \\
India & 1 & $0.35 \%$ \\
Mexico & 4 & $1.39 \%$ \\
Nicaragua & 13 & $4.51 \%$ \\
Peru & 4 & $1.39 \%$ \\
Pakistan & 85 & $29.51 \%$ \\
Paraguay & 21 & $7.29 \%$ \\
Saudi Arabia & 1 & $0.35 \%$ \\
El Salvador & 9 & $3.13 \%$ \\
United States & 5 & $1.74 \%$ \\
Uruguay & 2 & $0.69 \%$ \\
Venezuela & 42 & $14.58 \%$ \\
Unknown & 6 & $2.08 \%$ \\
\hline
\end{tabular}

As state by Castillo (2015), to consider a survey completed respondents had to answer all questions with the exception of name, phone and email address. Yet, country of respondents was stated using the IP address recorded by LimeSurvey ${ }^{\circledR}$ software, with a multiple IP address lookup application provided by the hosting company WEBNet77 (Castillo, 2015; WEBNet77, 2014).

\section{Sample Demographics}

As stated by Castillo (2015), participants' demographics are divided and presented below, by country, gender (male or female), marital status (married or single), age (under 20 years old, 21-30, 31-40, 41-50 and above 50), education level (secondary education, bachelor degree and graduate school), occupation (civil servant, retired, house wife, student, worker, self-employed, unemployed, private sector, employee and other) and income level (less than US\$500 per month, US\$ 501-US\$1000, US\$1001-US\$2000, US\$2001-US\$3000, US\$3001-US\$5000 and above US\$5000 per month).

Table 2: Sample Demographics: Responses by Country

\begin{tabular}{lll}
\hline Country & $\begin{array}{l}\text { \# Of Valid } \\
\text { Responses }\end{array}$ & $\begin{array}{l}\text { \% Valid } \\
\text { Responses }\end{array}$ \\
\hline Argentina & 3 & $1.04 \%$ \\
Bolivia & 43 & $14.93 \%$ \\
Canada & 4 & $1.39 \%$ \\
Chile & 3 & $1.04 \%$
\end{tabular}




\begin{tabular}{lll} 
Colombia & 5 & $1.74 \%$ \\
Egypt & 10 & $3.47 \%$ \\
France & 1 & $0.35 \%$ \\
Ghana & 1 & $0.35 \%$ \\
Guatemala & 15 & $5.21 \%$ \\
Honduras & 6 & $2.08 \%$ \\
Indonesia & 4 & $1.39 \%$ \\
India & 1 & $0.35 \%$ \\
Mexico & 4 & $1.39 \%$ \\
Nicaragua & 13 & $4.51 \%$ \\
Peru & 4 & $1.39 \%$ \\
Pakistan & 85 & $29.51 \%$ \\
Paraguay & 21 & $7.29 \%$ \\
Saudi Arabia & 1 & $0.35 \%$ \\
El Salvador & 9 & $3.13 \%$ \\
United States & 5 & $1.74 \%$ \\
Uruguay & 2 & $0.69 \%$ \\
Venezuela & 42 & $14.58 \%$ \\
Unknown & 6 & $2.08 \%$ \\
Total & 288 & $100 \%$ \\
\hline Note. Respond
\end{tabular}

Note. Respondents of 22 countries answered the survey.

Table 3: Sample Demographics: Gender

\begin{tabular}{lll}
\hline Gender & Frequency & $\%$ Valid \\
\hline Male & 235 & $81.60 \%$ \\
Female & 53 & $18.40 \%$ \\
Total & 288 & $100 \%$ \\
\hline Note & The majority of respondents were male.
\end{tabular}

Note. The majority of respondents were male.

Table 4: Sample Demographics: Marital Status

\begin{tabular}{lll}
\hline Marital Status & Frequency & $\%$ Valid \\
\hline Married & 90 & $31.25 \%$ \\
Single & 198 & $68.75 \%$ \\
Total & 288 & $100 \%$ \\
\hline
\end{tabular}

Note. Most of valid respondents were single

Table 5 Sample Demographics: Age

\begin{tabular}{lll}
\hline Age & Frequency & $\%$ Valid \\
\hline Under 20 years old & 14 & $4.86 \%$ \\
21-30 years old & 163 & $56.60 \%$ \\
$31-40$ years old & 57 & $19.79 \%$ \\
41-50 years old & 42 & $14.58 \%$ \\
Above 50 years old & 12 & $4.17 \%$ \\
Total & 288 & $100 \%$ \\
\hline
\end{tabular}

Note. The majority of respondents are between 21-30 years old. The second group was between 31-40 years old. Between both groups there is a total of 220 respondents or $76.39 \%$, plus a total of 54 respondents above 41 years old for a total of 274 participants that are 21 years old or older.

Table 6 Sample Demographics: Education Level

\begin{tabular}{lll}
\hline Education Level & Frequency & \% Valid \\
\hline Secondary Education & 50 & $17.36 \%$ \\
Bachelor's Degree & 188 & $65.28 \%$ \\
Graduate School & 50 & $17.36 \%$
\end{tabular}


Total $288 \quad 100 \%$

Note. The majority of respondents have a bachelor's degree.

Table 7 Sample Demographics: Occupation

\begin{tabular}{lll}
\hline Occupation & Frequency & $\%$ Valid \\
\hline Civil Servant & 22 & $7.64 \%$ \\
Retired & 3 & $1.04 \%$ \\
House Wife & 6 & $2.08 \%$ \\
Student & 75 & $26.04 \%$ \\
Worker & 28 & $9.72 \%$ \\
Self-Employed & 41 & $14.24 \%$ \\
Unemployed & 17 & $5.90 \%$ \\
Private Sector & 41 & $14.24 \%$ \\
Employee & 42 & $14.58 \%$ \\
Other & 13 & $4.51 \%$ \\
Total & 288 & $100 \%$ \\
\hline
\end{tabular}

Note. Most of respondents were students or employees.

Table 8 Sample Demographics: Income Level

\begin{tabular}{lll}
\hline Income Level & Frequency & $\%$ Valid \\
\hline Less than US\$500 per month & 169 & $58.68 \%$ \\
US\$501-US\$1000 & 84 & $29.17 \%$ \\
US\$1001-US\$2000 & 23 & $7.99 \%$ \\
US\$2001-US\$3000 & 5 & $1.74 \%$ \\
US\$3001-US\$5000 & 2 & $0.69 \%$ \\
Above US\$5000 per month & 5 & $1.74 \%$ \\
Total & 288 & $100 \%$ \\
\hline
\end{tabular}

Note. The majority of participants earn less than US\$500 per month, and the second group in importance earn between US\$501 - US\$1,000. Both groups represent a total of 253 respondents or $87.85 \%$.

Demographics show 274 or $95.14 \%$ participants with 21 years of age or older, 187 or $64.93 \%$ participants that are employed and have an income at the moment of the survey, 75 or $26.04 \%$ that are students, a total of 262 or $90.97 \%$ that are employees or students, 238 or $82.64 \%$ that have a university degree, and $100 \%$ that have secondary education or more (Castillo, 2015).

Schultz, Block and Labrecque (2012) state that Facebook's users commonly make recommendations to their friends on things of their interest like products, retail stores, and related experiences something that proves they are consumers of the retail industry (Kim, Kim \& Nam, 2010; Schultz, Block \& Labrecque, 2012; Yang, 2012).

\section{Presentation of Analysis}

The following results assess the variable customer empowerment based described surveys:

Table 9 Customer Empowerment

\begin{tabular}{lll}
\hline Rate & Count & Percentage \\
\hline 1 & 15 & $5.21 \%$ \\
2 & 18 & $6.25 \%$ \\
3 & 55 & $19.10 \%$ \\
4 & 81 & $28.12 \%$ \\
5 & 119 & $41.32 \%$ \\
Total & 288 & $100 \%$ \\
Mean & & 3.94 \\
Mean Lower Confidence Limit & & 3.83 \\
Mean Upper Confidence Limit & & 4.05 \\
Median & & 4.00 \\
Standard Deviation & & 1.15 \\
Variance & & 1.32 \\
Mode & & 5.00 \\
\hline
\end{tabular}


Also, the following results assess variable customer satisfaction:

Table 10 Customer Satisfaction

\begin{tabular}{lll}
\hline Rate & Count & Percentage \\
\hline 1 & 22 & $7.64 \%$ \\
2 & 23 & $7.99 \%$ \\
3 & 50 & $17.36 \%$ \\
4 & 65 & $22.57 \%$ \\
5 & 128 & $44.44 \%$ \\
Total & 288 & $100 \%$ \\
Mean & & 3.88 \\
Mean Lower Confidence Limit & & 3.76 \\
Mean Upper Confidence Limit & & 4.01 \\
Median & & 4.00 \\
Standard Deviation & & 1.27 \\
Variance & & 1.62 \\
Mode & 5.00 \\
\hline
\end{tabular}

The overall comparison for both variables is as follows (Castillo, 2015):

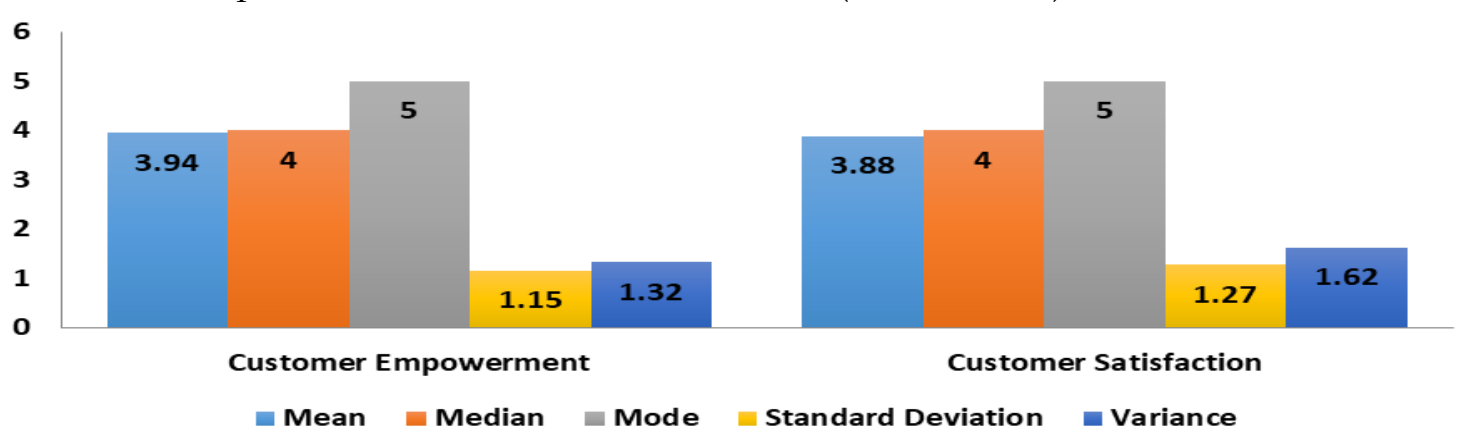

Figure 1. Overall Comparison

As shown on Figure 1 and Tables 9 and 10, customer empowerment and customer satisfaction have a high significance for participants with a mean above 3.88 , a median of 4 , a mode of 5 , a standard deviation of 1.15 and 1.27, and a variance of 1.32 and 1.62 respectively (Castillo, 2017).

Both variables are correlated through a simple linear regression and such correlation is tested through ANOVA and P-Value, the following values arise with a $90 \%$ confidence level:

$\mathrm{R}=40.72 \%$
$\mathrm{R} 2=16.58 \%$

Adjusted R2 $=16.29 \%$

$\mathrm{P}$-Value $=6.24 \mathrm{E}-13$

Thus, it can be inferred that there is a positive correlation of $40.72 \%$ between customer empowerment and customer satisfaction, a P-Value (ANOVA) of 6.24E-13 which is considerably below 0.10 , and an adjusted R2 stating that $16.29 \%$ of the times customer empowerment explains the perception of customer satisfaction, resulting in the rejection of null hypothesis ${ }_{1} \mathrm{H}_{0}$, and exposing a positive influence of such perception of empowerment over customers' satisfaction (Adams, Khan, \& Raeside, 2007; Creswell, 2013; Whaley, 2006, Castillo, 2017).

Independent variables (IV) of understanding customers' needs, discovering customers' preferences and suggesting products to customers based on their needs were analyzed using ANOVA and p-value with a 90\% confidence level and questions 11 through 15 with the same 5-point Likert scale as described on Appendix A and B (Adams, Khan \& Raeside, 2007; Creswell, 2013; Whaley, 2006).

For the independent variable (IV) of understanding needs, the question "Do you buy more from a salesperson that understand your needs?" was used on the web-survey. Such question evaluated the significance of understanding needs in a when a salesperson interacts with a customer as part of such 
process (Liu \& Leach, 2001; Palokangas, 2010; Suomala, Palokangas, Leminen, Westerlund, Heinonen, \& Numminen, 2012).

The second IV related to customer's preferences is evaluated through the web-survey when asking participants, "Do you buy more from a salesperson that asks if you like something that is being suggested by him based on your needs?" Such question comes to evaluate if suggesting products to customers that are preferred by them is an important factor for such customers to buy more, thus, assessing the importance of customers' preferences and its significance as an independent variable (Abdullah, Abdurahman, \& Hamali, 2013; Homburg, Wieseke, \& Bornemann, 2009).

Suggesting products is the third independent variable. Such variable and its importance are quantified when using the question "Do you buy more from a salesperson that suggests several products to you based on your needs?" which comes to assess the importance of suggesting products based on customers' needs (Chakrabarty, Brown \& Widing, 2010; Palokangas, 2010; Saxe \& Weitz, 1982; Smith, 2012; Wachner, Plouffe, \& Grégoire, 2009).

Explaining the warranty terms is also assessed as an independent variable using the question "Do you buy more from a salesperson that explains what you are entitled to when buying a product, in terms of returns, exchange and support of such products being sold?" Such question states the importance for participants acting as consumers, of mentioning such warranty terms and conditions (Agrawal, Richardson \& Grimm, 1996; Homburg, Wieseke, \& Bornemann, 2009; Murthy \& Djamaludin, 2002; Palokangas, 2010).

The following results were obtained when assessing all independent variables (Appendix B) based on 288 completed questionnaires, as stated previously.

Table 13 Independent Variable: Understanding Needs

\begin{tabular}{lll}
\hline Rate & Count & Percentage \\
\hline 1 & 16 & $5.56 \%$ \\
2 & 35 & $12.15 \%$ \\
3 & 49 & $17.01 \%$ \\
4 & 73 & $25.35 \%$ \\
5 & 115 & $39.93 \%$ \\
Total & 288 & $100 \%$ \\
Mean & & 3.82 \\
Median & & 4.00 \\
Mean Lower Confidence Limit & & 3.70 \\
Mean Upper Confidence Limit & & 3.94 \\
Standard Deviation & & 1.24 \\
Variance & & 1.53 \\
Mode & & 5.00 \\
\hline
\end{tabular}

Table 14 Independent Variable: Customer's Preferences

\begin{tabular}{lll}
\hline Rate & Count & Percentage \\
\hline 1 & 21 & $7.29 \%$ \\
2 & 38 & $13.19 \%$ \\
3 & 68 & $23.61 \%$ \\
4 & 69 & $23.96 \%$ \\
5 & 92 & $31.94 \%$ \\
Total & 288 & $100 \%$ \\
Mean & & 3.60 \\
Mean Lower Confidence Limit & & 3.48 \\
Mean Upper Confidence Limit & & 3.72 \\
Median & & 4.00 \\
Standard Deviation & & 1.26 \\
Variance & & 1.59 \\
Mode & & 5.00 \\
\hline
\end{tabular}


Table 15 Independent Variable: Suggesting Products

\begin{tabular}{lll}
\hline Rate & Count & Percentage \\
\hline 1 & 22 & $7.64 \%$ \\
2 & 32 & $11.11 \%$ \\
3 & 63 & $21.88 \%$ \\
4 & 79 & $27.43 \%$ \\
5 & 92 & $31.94 \%$ \\
Total & 288 & $100 \%$ \\
Mean & & 3.65 \\
Mean Lower Confidence Limit & & 3.53 \\
Mean Upper Confidence Limit & & 3.77 \\
Median & & 4.00 \\
Standard Deviation & & 1.25 \\
Variance & 1.55 \\
Mode & 5.00 \\
\hline
\end{tabular}

Table 16 Independent Variable: Warranty Terms

\begin{tabular}{lll}
\hline Rate & Count & Percentage \\
\hline 1 & 18 & $6.25 \%$ \\
2 & 22 & $7.64 \%$ \\
3 & 51 & $17.71 \%$ \\
4 & 72 & $25.00 \%$ \\
5 & 125 & $43.40 \%$ \\
Total & 288 & $100 \%$ \\
Mean & & 3.92 \\
Mean Lower Confidence Limit & & 3.80 \\
Mean Upper Confidence Limit & & 4.03 \\
Median & & 4.00 \\
Standard Deviation & & 1.22 \\
Variance & & 1.48 \\
Mode & 5.00 \\
\hline
\end{tabular}

When comparing means, median, mode, standard deviation, and variance for all independent variables as stated on Figure 2, all variables have a notorious importance for participants with similar descriptive statistics results. Mean for all variables is above 3.6, median is 4 , mode is 5 , standard deviation is less than 1.26 , and variance is less than 1.59 .

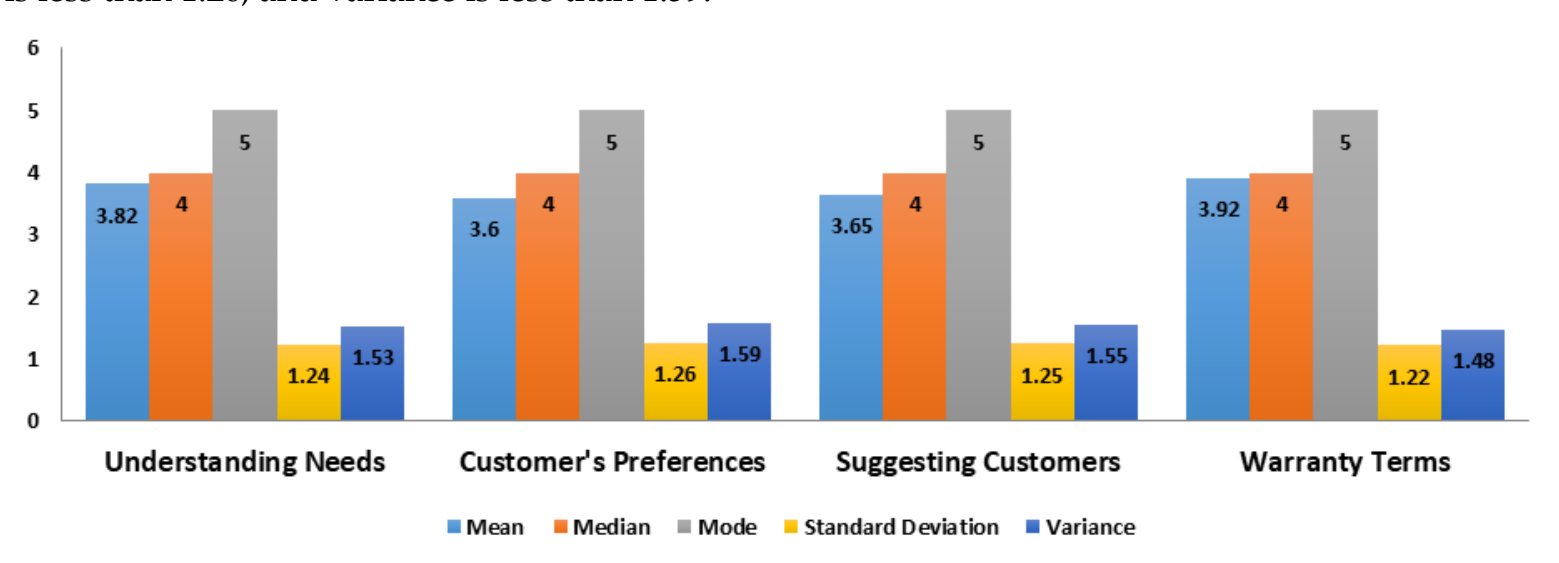

Figure 2. Independent Variables - Overall Comparison 
Table 17 Summary of Null Hypotheses Results (Including Warranty Terms)

\begin{tabular}{|c|c|c|c|}
\hline Null Hypothesis & Description & P-Value & Rejected? \\
\hline${ }_{1} \mathrm{H}_{0}$ & $\begin{array}{l}\text { There is no significant positive relation between Customer } \\
\text { Empowerment evoked during the consultative selling process } \\
\text { and Customer Satisfaction. }\end{array}$ & $6.24 \mathrm{E}-13$ & Yes \\
\hline${ }_{2} \mathrm{H}_{0}$ & $\begin{array}{l}\text { There is no significant positive relation between } \\
\text { Understanding Needs and Customer Satisfaction. }\end{array}$ & 6.90E-03 & Yes \\
\hline${ }_{3} \mathrm{H}_{0}$ & $\begin{array}{l}\text { There is no significant positive relation between } \\
\text { Understanding Needs and Customer Empowerment. }\end{array}$ & $1.08 \mathrm{E}-08$ & Yes \\
\hline${ }_{4} \mathrm{H}_{0}$ & $\begin{array}{l}\text { There is no significant positive relation between Customer's } \\
\text { Preferences and Customer Satisfaction. }\end{array}$ & $2.50 \mathrm{E}-01$ & No \\
\hline${ }_{5} \mathrm{H}_{0}$ & $\begin{array}{l}\text { There is no significant positive relation between Customer's } \\
\text { Preferences and Customer Empowerment. }\end{array}$ & $1.74 \mathrm{E}-01$ & No \\
\hline${ }_{6} \mathrm{H}_{0}$ & $\begin{array}{l}\text { There is no significant positive relation between Suggesting } \\
\text { Products to Customers and Customer Satisfaction. }\end{array}$ & 4.09E-02 & Yes \\
\hline${ }_{7} \mathrm{H}_{0}$ & $\begin{array}{l}\text { There is no significant positive relation between Suggesting } \\
\text { Products to Customers and Customer Empowerment. }\end{array}$ & 2.64E-02 & Yes \\
\hline
\end{tabular}

\section{Conclusions and Discussion}

The relationship between customer empowerment and customer satisfaction has been validated. Customers that perceive a State of Empowerment (SE) will incline to be more satisfied than those who don't feel empowered.

With this in mind, a perceived State of Empowerment becomes an important factor when interacting with consumers in a retail environment, either through a brick and mortar store or a web environment.

Activities such as Understanding Customers' Needs and Suggesting Products to Customers based on their needs (Appendix B) come to develop such SE. Also, independent variable Warranty Terms plays an important role in any interaction, since when removed null hypothesis for Suggesting Products to Customers gets accepted, denoting such terms are fundamental to cause an impact on customer empowerment and satisfaction when using the variable of suggesting products to customers. Last, Understanding Customers' Needs proves to have the highest correlation with a perceived State of Empowerment and is the most important activity a company may need to consider while interacting with consumers.

Therefore, it can be inferred that strategies to Understand Customers' Needs, Suggest Products to Customers, and Explain Warranty Terms, are the most significant if a high State of Empowerment and Customer Satisfaction is the main purpose of such organization. Such activities imply a special focus, and specific activities and measurements to assure their objective. Thus, to achieve a higher probability of success and gain market share and loyalty through a consultative selling process or an on-line retail interaction, such activities should be considered fundamental and play a critical role (Anitsal \& Anitsal, 2009; Castillo, 2017; Mulyanegara, Tsarenko \& Anderson, 2009; Rammstedt \& John, 2007; Žabkar \& Kolar, 2010).

\section{Limitations}

Three limitations have been identified. The study includes people from 22 countries willing to answer the survey, causing generalizations difficult to be totally supported around the world (Creswell, 2013). Nevertheless, Brenna and Coppack (2008), and Broderick, Demangeot, Adkins, Ferguson, Henderson, Johnson, Kipnis, Mandiberg, Mueller, Pullig, Roy, and Zúñiga (2011), explain the concept of customer empowerment and satisfaction is known in most countries, although, the meaning of such concept may vary. Thus, the present research aims to focus on a defined concept of a state of empowerment and satisfaction.

The second limitation is the use of two languages in the survey, English and Spanish, which represent a barrier for potential participants in non-English or Spanish speaking countries. Yet, Sullivan, and Cottone (2010) state "using different languages with different research participants was a strength and was evidence of study validity, rather than a source of possible error" and "awareness of language 
can contribute to a deeper understanding and does not necessarily introduce greater complication or error into a study" (p.360).

Third limitation is the possibility of have some respondents overstating their qualifications and income. Therefore, such likelihood needs to be factored when interpreting all findings.

\section{Future Research Suggestions}

How a store's environment or service model may impact such empowerment perception when customers have entire control over their transaction, becomes a related area of interest that may complement the present study.

Moreover, how words, statements, or sentences used in a selling process may create awareness of a "state of empowerment" in a retail environment, is another area of interest that could be expanded.

\section{References}

Abdullah, F., Abdurahman, A., \& Hamali, J. (2013). The Dimensions of Customer Preference in the Foodservice Industry, Business: Theory and Practice, 14(1), 64-73. Retrieved November 10, 2017, from EBSCO Research Database.

Agrawal, J., Richardson, P.S., \& Grimm, P.E. (1996). The Relationship Between Warranty and Product Reliability, The Journal of Consumer Affairs, 30(2), 421-443. Retrieved January 14, 2014, from EBSCO Research Database.

Adams, J., Khan, H.T.A., \& Raeside, R. (2007, August). Research Methods for Graduate Business and Social Science Students. New Delhi, India: Sage India.

Allik, J. (2005). Personality Dimensions Across Cultures, Journal of Personality Disorders, 19(3), 212-232. Retrieved October 31, 2016, from http:// psych.ut.ee/ jyri/en/Allik_JPD2005.pdf

American Psychological Association (2014). Ethical Principles of Psychologists and Code of Conduct. Retrieved November 24, 2014 from http://apa.org/ethics/code/index.aspx

Anitsal, M.M., \& Anitsal, I. (2009). Impact of Customers' Personality Traits in Retail Environments, Academy of Strategic Management Journal, 8(1), 39-50. Retrieved April 24, 2014, from EBSCO Research Database.

Betancourt-Ortiz, I., Meza-Téllez, M., \& Terrones-Castro, M. (2017, May-August). E-Commerce as Mechanism for Enhancing Micro and Small Enterprises: The Case of a Port Conurbated Area in the Southeast of Mexico, European Journal of Economics and Business Studies, 8(1), 65-72. Retrieved December 21, 2017, from http://journals.euser.org/files/articles/ejes_may_aug_17/Ignacio.pdf

Brennan, C., \& Coppack, M. (2008). Consumer Empowerment: Global Context, UK Strategies and Vulnerable Consumers, International Journal of Consumer Studies, 32(1), 306-313. Retrieved August 18, 2013, from EBSCO Research Database.

Broderick, A.J., Demangeot, C., Adkins, N.R., Ferguson, N.S., Henderson, G.R., Johnson, G., Kipnis, E., Mandiberg, J.M., Mueller, R.D., Pullig, C., Roy, A., \& Zúñiga, M.A. (2011). Consumer Empowerment in Multicultural Marketplaces: Navigating Multicultural Identities to Reduce Consumer Vulnerability, Journal of Research for Consumers, 19(1), 1-13. Retrieved August 21, 2013, from EBSCO Research Database.

Castillo, J. (2015, March). Impact of Customer Empowerment on Customer Satisfaction in the Retail Industry, Dissertation SMC University, 1-150.

Castillo, J. (2017, January). The Relationship Between Big Five Personality Traits, Customer Empowerment and Customer Satisfaction in The Retail Industry, Journal of Business and Retail Management Research, 11(2), 11-29. Retrieved July 31, 2017, from http://www.jbrmr.com/admin/content/pdf/i-26_c-253.pdf

Chakrabarty, S., Brown, G., \& Widing, R.E. (2010, Fall). The Effects of Perceived Customer Dependence on Salesperson Influence Strategies, Journal of Personal Selling \& Sales Management, 30(4), 327-341. Retrieved November 10, 2017, from EBSCO Research Database.

Creswell, J.W. (2013, March). Research Design. Qualitative, Quantitative, and Mixed Methods Approach (4th ed.). Los Angeles, CA: Sage Publications.

Deloitte (2014). Global Powers of Retailing 2014. Retrieved November 26, 2014, from

http://www.deloitte.com/assets/Dcom-Kenya/Local\%20Assets/Documents/CB_Global-Powers-of-Retailing2014.pdf

Di Mascio, R. (2010, July). The Service Models of Frontline Employees, Journal of Marketing, 74(1), 63-80. Retrieved July 15, 2013, from EBSCO Research Database.

EBSCO Industries, Inc. (2014). EBSCOhost. Retrieved August 27, 2013, from http:/ /www.ebscohost.com

Facebook (2014). Facebook Newsroom. Retrieved May 27, 2014, from http://newsroom.fb.com/company-info/

Fuchs, C., Prandelli, E., \& Schreier, M. (2010, January). The Psychological Effects of Empowerment Strategies on Consumers' Product Demand, Journal of Marketing, 74(1), 65-79. Retrieved April 26, 2014, from EBSCO Research Database. 
Graziano, J.E., \& Flanagan, P.J. (2005, January). Explore the Art of Consultative Selling, Journal of Accountancy, 199(1), 34-37. Retrieved April 8, 2014, from EBSCO Research Database.

Grewal, D., Krishnan, R., \& Lindsey-Mullikin, J. (2008). Building Store Loyalty Through Service Strategies, Journal of Relationship Marketing, 7(4), 341-358. Retrieved September 24, 2013, from EBSCO Research Database.

Heine, S.J., Buchtel, E.E., \& Norenzayan, A. (2008). What Do Cross-National Comparisons of Personality Traits Tell Us?, Association for Psychological Science, 19(4), 309-313. Retrieved October 31, 2016, from http://www2.psych.ubc.ca/ anlab/Manuscripts/HeineBuchNorenz_2008.pdf

Hennig-Thurau, T. (2004). Customer Orientation of Service Employees. International Journal of Service Industry Management, 15(5), 460-478. Retrieved July 18, 2013, from EBSCO Research Database.

Homburg, C., Wieseke, J., \& Bornemann, T. (2009, July). Implementing the Marketing Concept at the EmployeeCustomer Interface: The Role of Customer Need Knowledge, Journal of Marketing, 73(1), 64-81. Retrieved November 10, 2017, from EBSCO Research Database.

Hunter, G.L., \& Garnefeld, I. (2008). When Does Consumer Empowerment Lead to Satisfied Customers? Some Mediating and Moderating Effects of the Empowerment-Satisfaction Link, Journal of Research for Consumers, 15(1), 1-14. Retrieved August 1, 2013, from EBSCO Research Database.

International Markets Bureau. (2011, December). Market Indicator Report. Ottawa, ON: Government of Canada Agriculture and Agri-Food Canada. Retrieved November 3, 2013, from

http:/ / publications.gc.ca/collections/collection_2012/agr/A74-1-46-2012-eng.pdf

IMAP Inc. (2010). Retail Industry Global Report - 2010. Retrieved October 30, 2013, from

http://www.imap.com/imap/media/resources/IMAPRetailReport8_23CB9AA9C6EBB.pdf

Ivanauskienè, N., Auruškevičienè, V., Škudienè, V., \& Nedzinskas, Š. (2012). Customer Perceptions of Value: Case of Retail Banking, Organizations and Markets in Emerging Economies, 3(1), 75-88. Retrieved March 2, 2014, from EBSCO Research Database.

Kim, J.H., Kim, M., \& Nam, Y. (2010). An Analysis of Self-Construals, Motivations, Facebook Use, and User Satisfaction, International Journal of Human-Computer Interaction, 26(11-12), 1077-1099. Retrieved July 17, 2014, from EBSCO Research Database.

Kotni, D.P. (2011, October). Impact of Retail Services on Retail Sales. Journal of the Academy of Business and Retail Management, 6(1), 73-81. Retrieved November 8, 2013, from EBSCO Research Database.

KPMG (2013). 2013 Retail Industry Outlook Survey. Retrieved November 26, 2014, from

https://www.kpmg.com/US/en/IssuesAndInsights/ArticlesPublications/Documents/retail-outlook-survey2013.pdf

Likert, R. (1932, June). A Technique for the Measurement of Attitudes. Archives of Psychology, 22(1932-33), 5-55.

LimeSurvey Project Team, \& Schmitz, C. (2014). LimeSurvey: An Open Source survey tool / LimeSurvey Project Hamburg, Germany. Retrieved May 27, 2014, from http:/ / www.limesurvey.org

Lui, A.H., \& Leach, M.P. (2001, Spring). Developing Loyal Customers with a Value-adding Sales Force: Examining Customer Satisfaction and the Perceived Credibility of Consultative Salespeople, Journal of Personal Selling $\mathcal{E}$ Sales Management, 21(2), 147-156. Retrieved October 21, 2013, from EBSCO Research Database.

Miller, G. (2009). SPENT. Sex, Evolution, and Consumer Behavior. New York, NY: Viking.

Mulyanegara, R.C., Tsarenko, Y., \& Anderson, A. (2009). The Big Five and Bran Personality: Investigating the Impact of Consumer Personality on Preferences Towards Particular Brand Personality, Brand Management, 16(4), 234247. Retrieved October 24, 2013, from EBSCO Research Database.

Murthy, D.N.P., \& Djamaludin, I. (2002). New Product Warranty: A Literature Review, International Journal of Production Economics, 73(1), 231-260. Retrieved January 14, 2014, from EBSCO Research Database.

Muyeed, A. (2012, February). Customer Perception on Service Quality in Retail Banking in Developing Countries - A Case Study. International Journal of Marketing Studies, 4(1) 116-122. Retrieved July 18, 2013, from EBSCO Research Database.

Palokangas, L. (2010, April). Measuring the Willingness to Purchase Using Methods of Neuromarketing. Retrieved from http://neuroeconomics.laurea.fi/dokumentit/palokangas_thesis.pdf

Pranic, L., \& Roehl, W.S. (2012). Rethinking Service Recovery: A Customer Empowerment (CE) Perspective, Journal of Business Economics and Management, 13(2), 242-260. Retrieved August 1, 2013, from EBSCO Research Database.

Rammstedt, B., \& John, O.P. (2007). Measuring Personality in One Minute or Less: A 10-item Short Version of the Big Five Inventory in English and German, Journal of Research in Personality, 41(1), 203-212. Retrieved August 15, 2013,

http://www.westmont.edu/_academics/departments/psychology/documents/Rammstedt_and_John.pdf doi: 10.1016/j.jrp.2006.02.001

Sainy, R. (2010, September). A Study of the Effect of Service Quality on Customer Loyalty in Retail Outlets, Journal of Management, 7(2), 49-62. Retrieved August 19, 2013, from EBSCO Research Database. 
Saxe, R., \& Weitz, B.A. (1982, August). The SOCO Scale: A Measure of the Customer Orientation of Salespeople, Journal of Marketing Research, 19(1), 343-351. Retrieved March 19, 2014, from EBSCO Research Database.

Smith, J.G. (2012, Spring). An Investigation of Market Orientation's and Selected Personality Traits' Relationship with Dimensions of Customer Orientation in Salespersons, Marketing Management Journal, 22(1), 97-112. Retrieved November 19, 2017, from EBSCO Research Database.

Schultz, D.E., Block, M.P., \& Labrecque, L.I. (2012, Spring). Consumer Retailer Preference and Facebook: Friends or Foes?, International Journal of Integrated Marketing Communications, 4(1), 7-18. Retrieved July 15, 2014, from EBSCO Research Database.

Schmitt, D.P., Allik, J., McCrae, R.R., \& Benet-Martínez, V., I. (2007, March). The Geographic Distribution of Big Five Personality Traits, Journal of Cross-Cultural Psychology, 38(2), 173-212. Retrieved October 31, 2016, from http:// biculturalism.ucr.edu/pdfs/Schmitt\%20et\%20al_JCCP2007.pdf

Shrivastava, G., \& Shrisvastava, S. (2017, September). Analysis of Customer Behavior in Online Retail Marketplace Using Hadoop, International Journal of Innovative Research in Computer Science \& Technology, 5(5), 376-380. Retrieved December 21, 2017, from

http://www.ijircst.org/DOC/3_IRP592.pdf

Specht, J., Egloff, B., \& Schmukle, S.C. (2011). Stability and Change of Personality Across the Life Course: The Impact of Age and Major Life Events on Mean-Level and Rank-Order Stability of the Big Five, Journal of Personality and Social Psychology, 101(4), 862-882. Retrieved October 31, 2016, from http:/ / disjointedthinking.jeffhughes.ca/wp-content/uploads/2012/10/Specht-et-al.-2011.-Impact-of-age-andmajor-life-events-on-stability-of-the-Big-Five.pdf

Sullivan, C., \& Cottone, R. (2010, Summer). Emergent Characteristics of Effective Cross-Cultural Research: A Review of the Literature, Journal of Counseling E Development, 88(3), 357-362. Retrieved August 12, 2014, from EBSCO Research Database.

Suomala, J., Palokangas, L., Leminen, S., Westerlund, M., Heinonen, J., \& Numminen, J. (2012, December). Neuromarketing: Understanding Customers' Subconscious Responses to Marketing, Technology Innovation Management Review, 1(1), 12-21. Retrieved March 21, 2014, from

http:/ / timreview.ca/sites/default/files/article_PDF/Suomala_et_al_TIMReview_December2012.pdf

Thenmozhi, S.P., \& Dhanapal, D. (2010, February). Retail Service Quality - A Customer Perception Analysis, Global Management Review, 4(2), 1-6. Retrieved July 19, 2013, from EBSCO Research Database.

Wachner, T., Plouffe, C.R., \& Grégoire, Y. (2009, January). SOCO's Impact on Individual Sales Performance: The Integration of Selling Skills as a Missing Link, Industrial Marketing Management, 38(1), 32-44. Retrieved November 14, 2017, from EBSCO Research Database.

WEBNet77 (2014). Multiple IP Address Lookup. Retrieved May 27, 2014, from http://software77.net/geo-ip/multilookup/

Whaley, R.E. (2006). Derivatives: Markets, Valuation, and Risk Management. Hoboken, NJ: John Wiley \& Sons, Inc.

Wicks, A.M., \& Roethlein, C.J. (2009, Spring). A Satisfaction-Based Definition of Quality, Journal of Business $\mathcal{E}$ Economic Studies, 15(1), 82-97. Retrieved August 19, 2013, from EBSCO Research Database.

Yang, T. (2012, Spring). The Decision Behavior of Facebook Users, Journal of Computer Information Systems, 52(3), 50-59. Retrieved July 15, 2014, from EBSCO Research Database.

Yuen, E.F.T., \& Chan, S.S.L. (2010, September-December). The Effect of Retail Service Quality and Product Quality on Customer Loyalty, Journal of Database Marketing \& Customer Strategy Management, 17(3/4), 222-240. Retrieved July 29, 2013, from EBSCO Research Database.

Žabkar, V., \& Kolar, T. (2010). Consumers in Slovenia: Values, Personality Types and Consumerist Attitudes, Trziste / Market, 2(1), 205-222. Retrieved October 25, 2013, from EBSCO Research Database.

\section{Appendix A}

\section{Survey Questionnaire Used in the Quantitative Research}

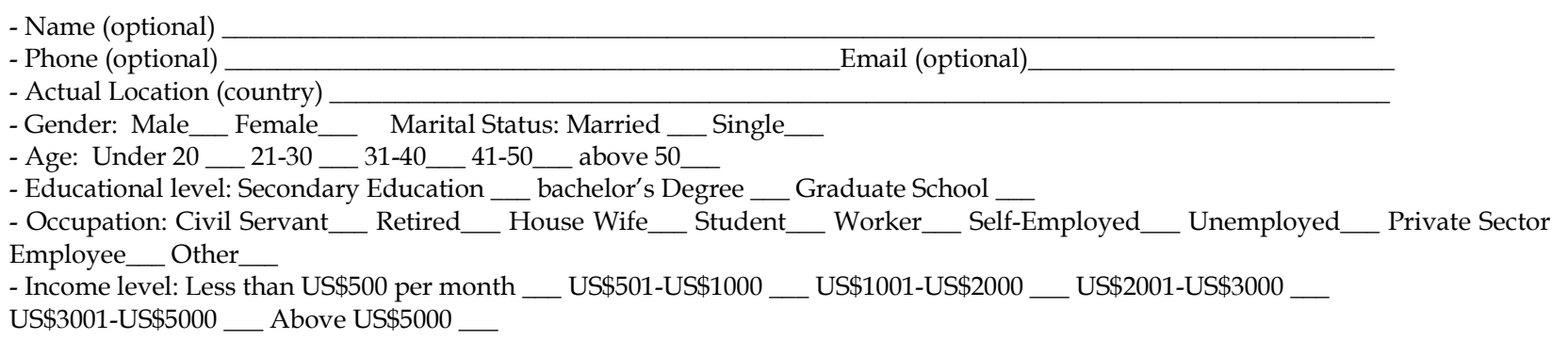




\begin{tabular}{|c|l|l|l|l|l|}
\hline I see myself as someone who... & $\begin{array}{l}\text { Disagree } \\
\text { strongly }\end{array}$ & $\begin{array}{l}\text { Disagree a } \\
\text { little }\end{array}$ & $\begin{array}{l}\text { Neither agree nor } \\
\text { disagree }\end{array}$ & Agree a little & $\begin{array}{l}\text { Agree } \\
\text { strongly }\end{array}$ \\
\hline$\ldots$ is reserved & $\mathbf{( 1 )}$ & $\mathbf{( 2 )}$ & $\mathbf{( 3 )}$ & $\mathbf{( 4 )}$ & $\mathbf{( 5 )}$ \\
\hline$\ldots$ is generally trusting & $\mathbf{( 1 )}$ & $\mathbf{( 2 )}$ & $\mathbf{( 3 )}$ & $\mathbf{( 4 )}$ & $\mathbf{( 5 )}$ \\
\hline$\ldots$ tends to be lazy & $\mathbf{( 1 )}$ & $\mathbf{( 2 )}$ & $\mathbf{( 3 )}$ & $\mathbf{( 4 )}$ & $\mathbf{( 5 )}$ \\
\hline$\ldots$ is relaxed, handles stress \\
well
\end{tabular}

11) Feeling empowered or with enough control during a selling process is important for you as a customer? (Strongly Disagree) 1 - - 2- - 3 - - 4 - -5 (Strongly Agree)

12) Do you buy more from a salesperson that understand your needs? (Strongly Disagree) 1 - - 2 - - 3 - - 4 - - 5 (Strongly Agree)

13) Do you buy more from a salesperson that asks if you like something that is being suggested by him based on your needs? (Strongly Disagree) 1 - - 2 - - 3 - - 4 - - 5 (Strongly Agree)

14) Do you buy more from a salesperson that suggests several products to you based on your needs? (Strongly Disagree) 1 - - 2 - - 3 - - 4 - - 5 (Strongly Agree)

15) Do you buy more from a salesperson that explains what you are entitled to when buying a product, in terms of returns, exchange and support of such products being (Strongly Disagree) 1 - - 2 - - 3 - - 4 - - 5 (Strongly Agree)

16) Receiving more service from a frontline employee compare to what you were expecting makes you buy more or feel better?

(Strongly Disagree) 1 - - 2 - - 3 - - 4 - - 5 (Strongly Agree)

\section{Appendix B \\ Variable Mapping}

\begin{tabular}{|l|l|l|}
\hline Variable Mapping and Survey Questionnaire \\
\hline Q\# & Question/Statement & Independent Variable \\
\hline Q11 & $\begin{array}{l}\text { Feeling empowered or with enough control during a selling } \\
\text { process is important for you as a customer? }\end{array}$ & State of Empowerment \\
\hline Q12 & $\begin{array}{l}\text { Do you buy more from a salesperson that understand your } \\
\text { needs? }\end{array}$ & $\begin{array}{l}\text { Asking consumers what they would like to } \\
\text { buy while showing them interest } \\
\text { (Understanding Needs) }\end{array}$ \\
\hline Q13 & $\begin{array}{l}\text { Do you buy more from a salesperson that asks if you like } \\
\text { something that is being suggested by him based on your needs? }\end{array}$ & $\begin{array}{l}\text { Asking costumers if they liked something } \\
\text { (Customer's Preferences) }\end{array}$ \\
\hline Q14 & $\begin{array}{l}\text { Do you buy more from a salesperson that suggests several } \\
\text { products to you based on your needs? }\end{array}$ & $\begin{array}{l}\text { Suggesting products to consumers based } \\
\text { on their needs (Suggesting Products to } \\
\text { Customers) } \\
\text { entitled to when buying a product, in terms of returns, exchange } \\
\text { and support of such products being sold? }\end{array}$ \\
\hline \multicolumn{2}{|l|}{ Q15 } & $\begin{array}{l}\text { Stating the warranty terms during the } \\
\text { customer journey (Warranty Terms) }\end{array}$ \\
\hline
\end{tabular}

\begin{tabular}{|l|l|l|}
\hline Variable Mapping and Survey Questionnaire \\
\hline Q \# & Question/Statement & Dependent Variable \\
\hline Q11 & $\begin{array}{l}\text { Feeling empowered or with enough control during a selling process is } \\
\text { important for you as a customer? }\end{array}$ & State of Empowerment \\
\hline Q16 & $\begin{array}{l}\text { Receiving more service from a frontline employee compare to what } \\
\text { you were expecting makes you buy more or feel better? }\end{array}$ & Customer Satisfaction Perception \\
\hline
\end{tabular}

